\title{
Examining the Intersections between Undergraduates' Engagement in Community Service and Development of Socially Responsible Leadership
}

\author{
Krista Soria \\ Analyst \\ Office of Institutional Research \\ University of Minnesota \\ Minneapolis, $\mathrm{MN}$ \\ ksoria@umn.edu \\ June Nobbe \\ Director \\ Leadership Education and Development \\ University of Minnesota \\ Minneapolis, MN \\ nobbe001@umn.edu \\ Alex Fink \\ School of Social Work \\ University of Minnesota \\ Minneapolis, MN \\ finkx082@umn.edu
}

\begin{abstract}
This paper examined relationships between students' engagement in community service in different contexts through classes, student organizations, work study, and on their own as well as their development of socially responsible leadership at a large, public, research university in the Upper Midwest. Results from the MultiInstitutional Study of Leadership survey distributed at a single institution $(n=$ 1,282 ) suggest, among other things, that students who participated in community service on their own consistently reported higher socially responsible leadership while students who participated in service both on their own and in a student organization reported higher socially responsible leadership in all areas save for consciousness of self.
\end{abstract}

\section{Introduction}

Many colleges and universities hold students' leadership development and community engagement central to their mission, vision, and values (Dugan, 2006). The increased presence of curricular and co-curricular student leadership development programs - in addition to the increased availability of and students' 
participation in community engagement endeavors - is further evidence of the increasing importance of leadership development and community engagement on college campuses (Astin \& Astin, 2000; Nishishiba \& Kecskes, 2012; The National Task Force on Civic Learning and Democratic Engagement, 2012; Zimmerman-Oster \& Burkhardt, 1999). Leadership development has been linked to several additional developmental outcomes among college students, including multicultural awareness, personal and societal awareness, and civic responsibility (Cress, Astin, Zimmerman-Oster, \& Burkhardt, 2001). In this study, we investigated the connections between undergraduate students' community service engagement and their development of socially responsible leadership.

We grounded this paper within the overarching framework of the social change model of leadership development, which suggests that student leadership development begins with the individual self, and moves outward toward the level of the community and eventually toward greater society. This framework in conjunction with the Socially Responsible Leadership Scale (Tyree, 1998) has previously been used to measure students' development of socially responsible leadership via their involvement in community service, positional roles, student organizations, and formalized leadership development programs (Dugan, 2006, 2008; Dugan, Komives, \& Segar, 2009). It is appropriate to consider the intersections between students' engagement in community service and their development of socially responsible leadership, as students who engaged in several types of community-based experiences may develop personal values such as (a) self-awareness and commitment to social causes, (b) group values such as collaborating with others and developing a shared sense of purpose and vision, and (c) societal and community values, such as individual responsibility to social change.

Examples abound when considering the many ways in which students' community experiences can foster their development of socially responsible leadership: in working with community organizations, students can learn how to collaborate and work effectively on a team. Students may also become inspired to engage in promoting social justice by directly witnessing the results of social injustice. Further, students can recognize and develop their own powerful sense of agency for participation in a democracy. Engagement in community service therefore has the potential to foster the development of socially responsible leadership within students (Dugan \& Komives, 2010). With those considerations in mind, this study focuses on one primary research question - Are there relationships between engagement in community service in different contexts through classes, in student organizations, on one's own, or through work study and students' development of socially responsible leadership when controlling for additional demographic, pre-college, and college leadership factors? 


\section{Community Service in College}

Community service continues to grow on college and university campuses across the United States. Recent figures from the Campus Compact suggest that college students contributed to more than 382 million hours of service in 2009-2010. According to the National Survey of Student Engagement, in 2010, 60\% of college seniors reported having completed community service or volunteer work. In addition, $65 \%$ of college freshmen reported that their respective universities offered opportunities to get involved in community service or community servicelearning (Liu, Ruiz, DeAngelo, \& Pryor, 2009), signaling the priority with which many colleges and universities place on providing community engagement opportunities for their college students.

Community service has been demonstrated to have positive effects on the personal development of college students by providing opportunities for students to become active, positive contributors to society. Researchers have also found that community service engagement or community service-learning is positively associated with heightened self-confidence, efficacy, and feelings of responsibility for the well-being of others (Eyler, Giles, \& Grey, 1999; Markus, Howard, \& King, 1993; Perry \& Katula, 2001). Other researchers have found such engagement during the college years to be associated with later engagement in community service as an adult (Giles \& Eyler, 1994; Oesterle, Johnson, \& Mortimer, 2004).

Community service experiences provide opportunities for college students to encounter new perspectives on the world through the development of connections with others. Youniss and Yates (1996) wrote that community service experiences can "promote a heightened and broadened sense of connection to other people [and] encourage reflections on moral and political questions" (p. 87). Further, Seider and Butin (2012) have noted that the community organizations through which college students engage in service often approach service with a "particular ideological orientation that the participating college students can consider, reject, or incorporate into their own developing worldviews" (p. 1), unleashing powerful opportunities for students to critically consider alternate viewpoints as they form their own identities and worldviews.

These extended benefits of community service in its various forms can influence students' leadership development by increasing opportunities for students to develop the values leading to positive social change in the social change model (HERI, 1996). Prior research has linked community service to students' leadership development; for example, Astin (1993) found that participation in volunteerism had positive associations with a commitment to developing a meaningful philosophy of life, promoting racial understanding, growth in cultural awareness, and interpersonal skills. Astin and Sax (1998) discovered that when controlling for freshmen year pre-tests, community service propensity, major, race, ethnicity, gender, and structural characteristics of the institution, community 
service engagement was positively associated with several life skills, including leadership abilities. In their extensive study, Dugan and Komives (2010) also found that participation in community service was a significant predictor in socially responsible leadership outcomes, save for consciousness of self and change.

Dugan (2006) also found that college students involved in community service scored higher than uninvolved peers on several leadership development values found within the social change model of development. While Dugan explored differences in the core leadership values between students who did and did not engage in community service, demographic factors and pre-college leadership experiences, antecedents, and efficacy were not considered in his models; therefore, this study attempts to expand upon Dugan's (2006) work to determine whether the effects of community service engagement hold when controlling for the influence of demographic, pre-college involvement and experiences, and incollege diversity experiences. This study is also unique because it examines whether student participation in community engagement in different contexts - in classes, with student organizations, through work study, or on one's own - are uniquely associated with students' socially responsible leadership.

\section{Conceptual Framework}

A few of the basic premises underlying the Social Change Model are that leadership should bring about positive social change, that leadership is a process and not a position, and that all students are potential leaders (Astin, 1996). A key assumption is that leadership is about effecting change on behalf of others and society. The model also assumes that leadership is a process, leadership is collaborative, and that service is a powerful vehicle for developing leadership skills. It outlines a leadership process that incorporates the principles of equity, inclusion, and service. The two primary goals of the model are to enhance student learning and development, particularly in the areas of self-knowledge and leadership competence, and to facilitate positive social change at the institution or in the community. The model examines leadership development from the perspectives of individual, group, and community and society.

The research team that developed the model identified seven core values, referred to as the "7 Cs" of leadership development for social change. Connected to the individual perspective are:

- Consciousness of self.

- Congruence.

- Commitment.

- Collaboration.

- Common purpose

- Controversy with civility.

- Citizenship. 
Change is the value hub that provides meaning and purpose to the seven core values. Interaction occurs between the individual, group and community/society levels and becomes a reciprocal process as reflection and active learning occur on a continuous cycle. It starts with the individual becoming more self-aware and then beginning to interact with others to ultimately effect change in community and society.

The model is intended to serve as a foundation for college student leadership development programs in order to "prepare a new generation of leaders who understand that they can act as leaders to effect change without necessarily being in traditional leadership positions of power and influence" (HERI, 1996, p. 12). Leadership in the context of positive social change, as the Social Change Model advocates, provides a relevant frame for examining student engagement in community service as it is associated with students' socially responsible leadership development.

\section{Methods}

In order to address our research question, we used ordinary least squares regression to analyze whether there are relationships between community service engagement and socially responsible leadership when controlling for additional factors.

\section{Instrument}

The Multi-Institutional Study of Leadership, which features the Socially Responsible Leadership Scale (Tyree, 1998) and is based on the social change model of leadership development (HERI, 1996), was the instrument used in this study. The Multi-Institutional Study of Leadership has been previously used in multiple research studies that have examined students' development of socially responsible leadership (Dugan, 2006, 2008; Dugan \& Komives, 2010; Dugan, Komives, \& Segar, 2009).

\section{Participants}

In 2009 the Multi-Institutional Study of Leadership (MSL) survey was distributed to 3,423 randomly selected undergraduate students at a large public university classified by the Carnegie Classification as having very high research activity. The undergraduate student population at this university was over 29,000 in 2009. The MSL survey was administered online and the response rate was $37.5 \%$ ( $n=$ $1,282)$. Our sample closely reflected institutional demographics, although more women completed the instrument than men (Table 1). The average age of respondents was 21.52 ( $\mathrm{SD}=4.32$ ). Our sample included a majority of non-firstgeneration (i.e., defined as parents having a bachelor degree of higher), full-time, and non-transfer students. 


\section{Measures}

Community service engagement. In order to capture students' engagement in community service, students were asked - In an average academic term, do you engage in any community service? Students responded by answering in the affirmative or negative. We discovered that $45.7 \%(n=585)$ students indicated engaging in community service in an average academic term. This question also acted as a filter variable to the question, "In an average academic term, approximately how many hours do you engage in community service?" It provided four categories in which students could select the average hours they participate in community service in each area.

Some students indicated participating in service in more than one context (e.g., engaging in service through classes and in student organizations); therefore, we wanted to acknowledge the multiple contexts in which students engage in service and also interrogate whether those contexts are uniquely associated with students' socially responsible leadership. To achieve that goal, we dummy-coded the variables and included all of the possible combinations of service context. We discovered that very few students participated in community service through work study (e.g., .4\% participated in service through both classes and in work study); therefore, we collapsed the work study-related variables into one primary category except in instances where students participated in service through classes, organizations, work, and on their own and when they participated in service through classes, organizations, and work.

This left us with nine categories representing students' participation in community service in singular or multiple contexts. In our sample, $13.2 \%(n=167)$ of students participated in community service as part of a class, $27.2 \%$ through a student organization ( $n=167), 6.0 \%$ through work study $(n=76)$, and $35.2 \%$ participated in service on their own $(n=449)$. Those figures are not mutually exclusive, as students could select more than one context in which they had participated in community service. Therefore, when we consider students' multiple participation through several contexts, we discovered that $3.8 \%(n=48)$ participated in service through work study (which included work study only and combinations of work study and student organizations, classes, etc.); $12.5 \%$ ( $n=$ $160)$ participated only on their own; 6.3\% $(n=80)$ participated through a student organization only; $1.3 \%(n=16)$ participated through a class only; $2.9 \%(n=37)$ participated both in a class on their own; $1.4 \%(n=18)$ participated through a class and a student organization; 4.9\% $(n=63)$ through a class, student organization, and work study; and $1.8 \%(n=23)$ through a class, student organization, work study, and on their own.

Demographics and background characteristics. Students were also asked to self-report their gender, race/ethnicity, transfer status, parents' educational attainment, and whether they were currently attending college full-time or part- 
time. Those variables were dummy-coded accordingly (see Table 1). Finally, as Dugan, Kodama, and Gebhardt (2012) found different predictors of leadership development by racial groups, we dummy-coded separate racial groups (AfricanAmerican, Asian-American, Native American, and Hispanic or Latino) with White and other or unknown students as the referent groups.

Pre-college leadership antecedents and involvement. Prior research has demonstrated the importance of students' pre-college experiences in predicting students' college experiences; for example, Astin's (1993) Input-EnvironmentOutcome model considers the importance of students' pre-college characteristics in examining college student growth or development. Along those lines, the MSL survey also asked students about their pre-college involvement in student activities and community service, confidence conducting leadership tasks, and diversity experiences. We considered these items to be important antecedents to students' leadership development and capacity to engage in socially responsible behaviors.

Pre-college leadership antecedent items related to students' participation in clubs, leadership positions, and volunteer work in high school. Additional antecedents referred to students' high school leadership experience, how often they were given positive feedback or encouragement regarding their leadership ability, or how often they saw others as leaders. Pre-college leadership self-efficacy items referred to students' confidence completing leadership tasks. Students' engagement in socially responsible leadership before they attended college was also used in analysis.

College leadership antecedents and involvement. In considering factors that would influence students' development of socially responsible leadership, we wanted to control for the influence of students' leadership experience and training in college. We also considered whether students had been involved in college organizations or held a leadership position in a college organization. Finally, we also considered the importance of sociocultural conversations on students' development of socially responsible leadership. 


\section{Table 1}

Means, Standard Deviations, and Coding for Variables

\begin{tabular}{|c|c|c|c|}
\hline Variables Used in Analysis & $M$ & $S D$ & Coding/Scale \\
\hline \multicolumn{4}{|l|}{ Demographic and Personal Characteristics } \\
\hline Gender & 61 & .49 & $0=\mathrm{m} ; 1=\mathrm{f}$ \\
\hline African American & .03 & .18 & $0=$ no $; 1=$ yes \\
\hline Asian Pacific American & .03 & .17 & $0=$ no $; 1=$ yes \\
\hline American Indian & .11 & .31 & $0=$ no $; 1=$ yes \\
\hline Hispanic or Latino & .01 & .09 & $0=$ no $; 1=$ yes \\
\hline Full-time enrollment & .91 & .28 & $0=$ no $; 1=$ yes \\
\hline Transfer student & .27 & .45 & $0=$ no $; 1=$ yes \\
\hline First-generation & .38 & .49 & $0=$ no $; 1=$ yes \\
\hline Level & 2.73 & 1.16 & $1=\mathrm{F}$ to $4=\mathrm{Sr}$ \\
\hline \multicolumn{4}{|l|}{ College Experiences } \\
\hline Discussed major social issues & 2.67 & .96 & $1=\mathrm{N}$ to $4=\mathrm{V} \mathrm{O}$ \\
\hline Discussions with students with values different than own & 2.85 & .86 & $1=\mathrm{N}$ to $4=\mathrm{V} \mathrm{O}$ \\
\hline Discussions with students with different religious beliefs & 2.62 & .95 & $1=\mathrm{N}$ to $4=\mathrm{V} \mathrm{O}$ \\
\hline Discussed views about multiculturalism & 2.65 & .94 & $1=\mathrm{N}$ to $4=\mathrm{V} \mathrm{O}$ \\
\hline Discussions with students with different political views & 2.72 & .95 & $1=\mathrm{N}$ to $4=\mathrm{V} \mathrm{O}$ \\
\hline Talked about different lifestyles/customs & 2.91 & .85 & $1=\mathrm{N}$ to $4=\mathrm{V} \mathrm{O}$ \\
\hline Short-term leadership experiences & 1.88 & .92 & $1=\mathrm{N}$ to $4=\mathrm{M}$ \\
\hline Moderate-term leadership experiences & 1.61 & .87 & $1=\mathrm{N}$ to $4=\mathrm{M}$ \\
\hline Long-term leadership experiences & 1.31 & .73 & $1=\mathrm{N}$ to $4=\mathrm{M}$ \\
\hline Held a leadership position in college organizations & 1.90 & 1.35 & $1=\mathrm{N}$ to $5=\mathrm{M} \mathrm{T}$ \\
\hline \multicolumn{4}{|l|}{ Pre-College Antecedents } \\
\hline Participation in student clubs/groups & 2.73 & 1.06 & $1=\mathrm{N}$ to $4=\mathrm{V} \mathrm{O}$ \\
\hline Participation in leadership positions & 2.41 & 1.14 & $1=\mathrm{N}$ to $4=\mathrm{V} \mathrm{O}$ \\
\hline Volunteer work & 2.41 & .87 & $1=\mathrm{N}$ to $4=\mathrm{V} \mathrm{O}$ \\
\hline $\begin{array}{l}\text { Amount of prior leadership experiences in student clubs, } \\
\text { performing groups, service orgs, (etc.) }\end{array}$ & 3.23 & 1.13 & $1=$ No to $5=E x$ \\
\hline $\begin{array}{l}\text { How often students have been given positive feedback or } \\
\text { encouragement for their leadership ability }\end{array}$ & 3.39 & 1.13 & $1=\mathrm{N}$ to $5=\mathrm{F}$ \\
\hline $\begin{array}{l}\text { How students would have reacted to being chosen or } \\
\text { appointed the leader of a group }\end{array}$ & 3.56 & 1.12 & $1=\mathrm{VU}$ to $5=\mathrm{VC}$ \\
\hline How often students saw others as effective leaders & 3.43 & .87 & $1=\mathrm{N}$ to $5=\mathrm{F}$ \\
\hline How often students thought of themselves as leaders & 3.27 & 1.13 & $1=\mathrm{N}$ to $5=\mathrm{F}$ \\
\hline Leading others & 2.69 & .89 & $1=\mathrm{NAC}$ to $4=\mathrm{VC}$ \\
\hline Organizing a group's tasks to accomplish goal & 2.82 & .85 & $1=\mathrm{NAC}$ to $4=\mathrm{VC}$ \\
\hline Working with team on group project & 3.03 & .79 & $1=\mathrm{NAC}$ to $4=\mathrm{V} \mathrm{C}$ \\
\hline $\begin{array}{l}\text { Hearing differences in opinions enriched my thinking } \\
\text { (controversy with civility) }\end{array}$ & 3.94 & .79 & $1=\mathrm{SD}$ to $5=\mathrm{SA}$ \\
\hline I had low self-esteem (consciousness of self) & 3.57 & 1.15 & $1=\mathrm{SD}$ to $5=\mathrm{SA}$ \\
\hline $\begin{array}{l}\text { I enjoyed working with others toward common goals } \\
\text { (collaboration) }\end{array}$ & 3.87 & .81 & $1=\mathrm{SD}$ to $5=\mathrm{SA}$ \\
\hline $\begin{array}{l}\text { I hold myself accountable for responsibilities I agree to } \\
\text { (commitment) }\end{array}$ & 4.25 & .73 & $1=\mathrm{SD}$ to $5=\mathrm{SA}$ \\
\hline $\begin{array}{l}\text { I worked well when I knew the collective values of a group } \\
\text { (common purpose) }\end{array}$ & 3.92 & .69 & $1=\mathrm{SD}$ to $5=\mathrm{SA}$ \\
\hline My behaviors reflected my beliefs (congruence) & 3.95 & .82 & $1=\mathrm{SD}$ to $5=\mathrm{SA}$ \\
\hline I value the opportunities that allow me to contribute to my & 3.67 & .87 & $1=\mathrm{SD}$ to $5=\mathrm{SA}$ \\
\hline
\end{tabular}


Community Service Participation

As part of a class only

With a student organization only

On your own only

.07

.07

$.05-.21$

Work study-related

Through student organizations and on one's own

$.04 \quad .20$

Through class and student organizations

.01

Through class and on one's own

.07

Through class, student organizations, and work study

.01

Through class, student organizations, work study, and on

.02

.01

.10

.13

.08

$$
\begin{aligned}
& 0=\text { no; } 1=\text { yes } \\
& 0=\text { no; } 1=\text { yes } \\
& 0=\text { no; } 1=\text { yes } \\
& 0=\text { no; } 1=\text { yes } \\
& 0=\text { no; } 1=\text { yes } \\
& 0=\text { no; } 1=\text { yes } \\
& 0=\text { no; } 1=\text { yes } \\
& 0=\text { no; } 1=\text { yes }
\end{aligned}
$$
one's own

Factor analysis. In order to derive factors from those items, we conducted a factor analysis on 28 items with oblique rotation (promax). The Kaiser-MeyerOlkin measure verified the sampling adequacy for the analysis $(\mathrm{KMO}=.90)$. Bartlett's test of sphericity $x^{2}(378)=14668.14, p<.001$, indicated that correlations between items were sufficiently large. An initial analysis was run to obtain eigenvalues for each component in the data; five components had an eigenvalue over Kaiser's criterion of one and explained $57.30 \%$ of the variance. Given the large sample size, Kaiser's criteria components, and the convergence of a scree plot that showed inflexions that justify retaining five components, the final analysis retained the following factors: sociocultural discussions, pre-college leadership antecedents, pre-college leadership efficacy, college leadership experience, and pre-college socially responsible leadership. Table 2 shows the factor loadings after rotation in a component matrix, with factor loadings over .35 in bold. Each component had a high reliability, with Cronbach's $\alpha>.70$. The factor scores were computed using the regression method and saved as standardized scores with a mean of zero and a standard deviation of one. 
Table 2

Summary of Factor Analysis Results for the MSL Questionnaire $(\mathrm{n}=1,190)$

\begin{tabular}{|c|c|c|c|c|c|}
\hline Item & 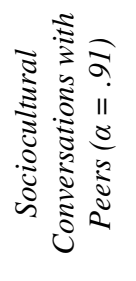 & 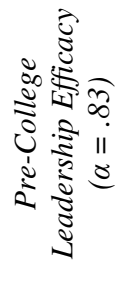 & 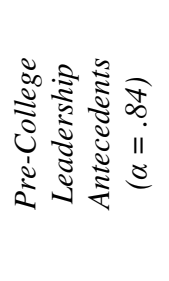 & 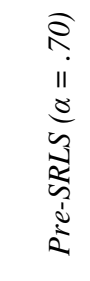 & 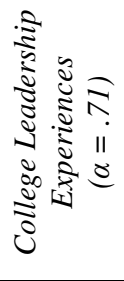 \\
\hline Discussed major social issues & .855 & -.025 & .002 & -.045 & .005 \\
\hline Discussed views about multiculturalism & .850 & -.038 & .001 & .007 & .029 \\
\hline $\begin{array}{l}\text { Discussions with students with values different than } \\
\text { own }\end{array}$ & .829 & .025 & .014 & .043 & .016 \\
\hline Talked about different lifestyles/customs & .822 & .012 & -.044 & .015 & .025 \\
\hline $\begin{array}{l}\text { Discussions with students with different religious } \\
\text { beliefs }\end{array}$ & .821 & -.074 & .048 & .011 & -.010 \\
\hline $\begin{array}{l}\text { Discussions with students with different political } \\
\text { views }\end{array}$ & .768 & .117 & -.015 & -.008 & -.019 \\
\hline Leading others & .014 & .908 & -.070 & -.051 & .051 \\
\hline Organizing a group's tasks to accomplish goal & .045 & .857 & -.122 & .020 & .053 \\
\hline Reaction to appointment as leader & -.001 & .697 & -.199 & .208 & .112 \\
\hline Working with team on group project & .029 & .656 & .272 & -.070 & -.120 \\
\hline Thinking of yourself as a leader & -.005 & .599 & .379 & -.057 & -.064 \\
\hline I had low self-esteem (consciousness of self) & -.112 & .569 & -.065 & .170 & .004 \\
\hline Pre-college participation in student clubs/groups & .001 & -.090 & .841 & -.080 & .037 \\
\hline Pre-college volunteer work & .001 & -.250 & .767 & .135 & .056 \\
\hline Pre-college participation in leadership positions & -.012 & .142 & .757 & -.094 & .031 \\
\hline $\begin{array}{l}\text { Amount of prior leadership experiences in } \\
\text { student clubs, performing groups, service } \\
\text { organizations, jobs (etc.) }\end{array}$ & -.011 & .336 & .630 & -.043 & -.010 \\
\hline $\begin{array}{l}\text { Given positive feedback or encouraged leadership } \\
\text { ability }\end{array}$ & .086 & .289 & .491 & .057 & -.089 \\
\hline Seeing others as effective leaders & -.016 & -.085 & .366 & .306 & -.022 \\
\hline $\begin{array}{l}\text { I worked well when I knew the collective values of } \\
\text { a group (common purpose) }\end{array}$ & -.013 & .113 & .028 & .680 & .002 \\
\hline $\begin{array}{l}\text { I hold myself accountable for responsibilities I } \\
\text { agree to (commitment) }\end{array}$ & -.002 & .084 & -.061 & .664 & -.083 \\
\hline My behaviors reflected my beliefs (congruence) & -.033 & .047 & -.041 & .639 & -.059 \\
\hline $\begin{array}{l}\text { I enjoyed working with others toward common } \\
\text { goals (collaboration) }\end{array}$ & -.017 & .217 & .008 & .551 & .063 \\
\hline $\begin{array}{l}\text { I value the opportunities that allow me to contribute } \\
\text { to my community (citizenship) }\end{array}$ & -.067 & -.161 & .432 & .528 & .126 \\
\hline $\begin{array}{l}\text { Hearing differences in opinions enriched my } \\
\text { thinking (controversy with civility) }\end{array}$ & .284 & -.102 & -.028 & .466 & -.087 \\
\hline Moderate-term leadership experiences & .014 & .038 & -.047 & -.023 & .832 \\
\hline Long-term leadership experiences & -.036 & .073 & -.058 & .009 & .788 \\
\hline Short-term leadership experiences & .077 & -.047 & .083 & -.019 & .736 \\
\hline Leadership position in college & -.009 & .027 & .159 & -.093 & .591 \\
\hline
\end{tabular}


Organizations

Socially responsible leadership development. Outcome variables were operationalized using the Socially Responsible Leadership Scale (SRLS). This instrument includes seven separate scales, each of which measures a particular socially responsible leadership value associated with the Social Change Model: consciousness of self, congruence, commitment, collaboration, common purpose, controversy with civility, and citizenship (Tyree, 1998). The SRLS also measures an eighth variable, change, which was not used as an outcome variable in this study, as our goal was to measure the "7 Cs." The SRLS contains a total of 68 items for which participants self-report their agree using a 5-point Likert-scale ranging from strongly disagree (1) to strongly agree (5) (with negative items reversed for calculation). For example, students would rate their agreement to the following item related to consciousness of self is "I know myself pretty well." The SRLS scale computes each factor by generating mean values, and each construct comprises between seven and 11 items. In our sample, the descriptive statistics (means and standard deviations) and internal reliability (Cronbach's alpha) for each scale is as follows: consciousness of self $(\mathrm{M}=3.95, \mathrm{SD}=.49, \alpha=$ $.79)$, congruence $(\mathrm{M}=4.13, \mathrm{SD}=.44, \alpha=.78)$, commitment $(\mathrm{M}=4.19, \mathrm{SD}=.46$, $\alpha=.80)$, collaboration $(\mathrm{M}=3.94, \mathrm{SD}=.46, \alpha=.82)$, common purpose $(\mathrm{M}=3.99$, $\mathrm{SD}=.41, \alpha=.79)$, controversy with civility $(\mathrm{M}=3.84, \mathrm{SD}=.41, \alpha=.75)$, citizenship $(\mathrm{M}=3.82, \mathrm{SD}=. .44, \alpha=.74)$.

\section{Examining Assumptions}

In all of our regressions, we examined assumptions of multicollinearity, homoscedasticity, linearity, and independent/normal errors. We found that multicollinearity assumptions were not violated (tolerance statistics were between .87 and variance inflation factors ranged from 1.04 to 1.78). Additionally, the highest bivariate correlation observed was less than .57 (between pre-college leadership efficacy and leadership antecedents). In testing homoscedasticity, we found random scatter and variability in scatterplots of standardized residuals against the standardized predicted values. In producing histograms of standardized residuals and normal probability plots comparing the distribution of standardized residuals to a normal distribution, we found evidence for normality. Examinations of matrix scatterplots suggested the relationships between the predictor and outcome variables were relatively linear. We found consistently that the residual errors were independent across our models (the Durbin-Watson values ranged from 1.59 to 1.99 ).

\section{Limitations}


Our study has several limitations that might constrain generalizability to other populations; for example, the survey was administered at a large, public research university located in an urban region of the Upper Midwest of the United States. All data collected were self-reported from students and institutional identifiers were not collected to verify students' demographic information. The overall variance explained in our models was around 30-40\%, leaving $60-70 \%$ of the variance unexplained in our analysis. The survey was also collected at one point in time without gleaning awareness of the potential impacts of long-term or shortterm involvement in community service. There are many dimensions and terms associated with community service, so it is unclear how individual students considered their engagement in community service when responding to the survey. While in some ways a limitation, this breadth of this term is also an opportunity to capture a number of different kinds of community service experiences that might otherwise be lost when considering stricter or refined definitions.

\section{Results}

We conducted ordinary least squares regressions with seven of the socially responsible leadership scales as dependent variables and students' participation in a variety of community service contexts, including considerations of students' participation in more than one context (e.g., through a student organization and through a class). We also controlled for demographic and personal characteristics along with the additional five factors hypothesized to impact students' socially responsible leadership values: sociocultural discussions, college leadership experiences, pre-college leadership antecedents, pre-college leadership selfefficacy, and pre-college socially responsible leadership.

Our first model predicting the socially responsible leadership value consciousness of self was statistically significant, $F(23,1054)=20.15, p<.001$, and the model explains $30.5 \%$ of the variance in consciousness of self (see Table 3 ). In this model, only students who participated in community service on their own without an association with a formal organization or course - reported higher consciousness of self than their referent groups. While no other forms of community service participation were significant, this model suggested that class level, sociocultural discussions, college leadership, pre-college socially responsible leadership, and pre-college leadership antecedents were positively associated with students' consciousness of self. Asian-American and Pacific Islander students reported lower consciousness of self and pre-college leadership efficacy was negatively associated with consciousness of self. In reviewing the standardized coefficients $(\beta)$, the model suggests that community service was not as strong in predicting students' consciousness of self $(\beta=.085)$ as are students' 
sociocultural discussions $(\beta=.236$ ), college leadership (which emerged as the strongest predictor, $\beta=.330$ ), and pre-tests for socially responsible leadership ( $\beta$ $=.169$ ).

Our second model predicting congruence was statistically significant, $F(23,1056)$ $=15.62, p<.001$, and the model accounts for $25.4 \%$ of the variance in congruence. This model suggests that students who participated in community service on their own and in two areas - on their own and with a student organization - reported higher congruence than their referent groups. As in the previous model, Asian-American and Pacific Islander students reported lower congruence while college level, sociocultural discussions, college leadership, and students' pre-college socially responsible leadership were positively associated with students' congruence. The standardized coefficients also suggested that participation in community service in both contexts was not as strongly predictive of students' congruence as students' sociocultural discussions, college leadership, and pre-tests for socially responsible leadership which was the strongest predictor in the model. The model also suggests that service on one's own and service in both organizations and on one's own were closely related in regards to their predictive strength of congruence $(\beta=.071$ and $\beta=.061$ respectively).

Our third model predicting commitment was statistically significant, $F(23,1056)$ $=17.31, p<.001$, and the model explains $27.4 \%$ of the variance in commitment. This model suggests that students who participated in (a) service on their own, (b) in a student organization and on their own, and (c) with a class, a student organization, and on their own all reported higher commitment than their referent groups. Asian-American and Pacific Islander students reported lower commitment while sociocultural discussions, college leadership, pre-college socially responsible leadership, and pre-college leadership antecedents were positively associated with students' commitment. In this model, participation in the three community service contexts was again moderately predictive of commitment, although the standardized coefficients for students who participated in service on their own and those who participated through both a student organization and on their own were higher than pre-college leadership antecedents and closer to that of sociocultural discussions and college leadership than in previous models.

Our fourth model predicting collaboration was statistically significant, $F$ (23, $1055)=24.93, p<.001$, and the model accounts for $35.2 \%$ of the variance in collaboration. This particular model suggested that students who participated in the following community service contexts reported greater collaboration than their referent groups - (a) service on one's own only, (b) service with a student organization only, (c) service with a class and student organization, (d) service with a student organization and on one's own, and (e) service with a class, with a student organization, and on one's own. Sociocultural discussions, college 
leadership, pre-college socially responsible leadership, and pre-college leadership antecedents were positively associated with students' collaboration. The standardized coefficients for all forms of community service were more predictive of college leadership yet lower than sociocultural discussions, pre-tests for socially responsible leadership, and pre-college leadership antecedents.

Our fifth model predicting common purpose was statistically significant, $F(23$, $1057)=21.76, p<.001$, and the model accounts for $32.1 \%$ of the variance in common purpose. This model suggested that students who participated in community service in the following contexts reported greater common purpose than their referent groups - (a) service on one's own only, (b) service with a student organization only, (c) service with a student organization and on one's own, and (d) service with a class, with a student organization, and on one's own. Asian-American and Pacific Islander students reported lower common purpose than their referent groups while class level, sociocultural discussions, college leadership, pre-college socially responsible leadership, and pre-college leadership antecedents were positively associated with students' common purpose. In this model, participation in the four contexts of community service were again moderately predictive of commitment and lower than the sociocultural conversations, college leadership, pre-tests for socially responsible leadership, and pre-college leadership antecedents.

Our sixth model predicting controversy with civility was statistically significant, $F(23,1056)=24.04, p<.001$, and the model explains $34.4 \%$ of the variance in controversy with civility. Students who participated in community service in three reported greater controversy with civility than their referent groups - (a) service on one's own, (b) service with a student organization and on one's own, and (c) service as a part of work study. Like the previous models college leadership, class level, sociocultural discussions, and pre-college socially responsible leadership were positively associated with controversy with civility. Within this model only service participation in a student organization and on one's own was more predictive of college leadership while all of the other forms of service were less predictive than sociocultural discussions and pre-college socially responsible leadership

Our seventh model predicting citizenship was statistically significant, $F(23,1056)$ $=28.98, p<.001$, and the model accounts for $38.7 \%$ of the variance in citizenship. This model suggests that students who participated in community service in the following contexts reported higher citizenship - (a) service on one's own only, (b) service with a class and student organization, (c) service with a class and on one's own, (d) service with a student organization and on one's own, (e) service with a class, a student organization, and on one's own, and (f) service in work study contexts. Asian American and Pacific Islander students reported 
lower citizenship compared to their referent groups while Hispanic or Latino students reported greater citizenship. Finally, sociocultural discussions, college leadership, pre-college leadership efficacy, pre-college socially responsible leadership, and pre-college leadership antecedents were positively associated with citizenship. Examinations of the standardized coefficients in this model suggest that participation in community service on one's own is more highly predictive of citizenship than college leadership, pre-college leadership efficacy, and precollege leadership antecedents. Participation in most of the community service contexts (save for service through a class and on one's own and service through a class, student organization, and on one's own) was more strongly predictive of citizenship than pre-college leadership efficacy. Sociocultural discussions and pre-college socially responsible leadership remain the greatest predictors, as was the case for all of the models.

Table 3

Regression Models Predicting Socially Responsible Leadership Scales

\begin{tabular}{|c|c|c|c|c|c|c|c|}
\hline & 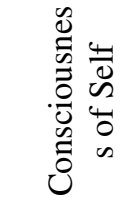 & 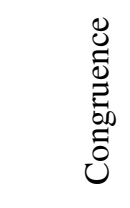 & 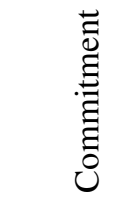 & 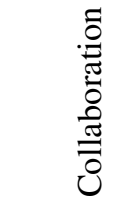 & 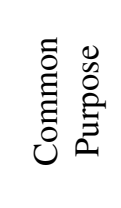 & 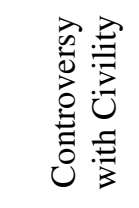 & 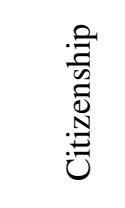 \\
\hline Predictor & $\beta$ & $\beta$ & $\beta$ & $\beta$ & $\beta$ & $\beta$ & $\beta$ \\
\hline Service on one's own only & $.085 *$ & $.071 *$ & $.087 * *$ & $.098 * * *$ & $.082 * *$ & $.068 *$ & $.154 * * *$ \\
\hline $\begin{array}{l}\text { Service with a student } \\
\text { organization only }\end{array}$ & .032 & .022 & .039 & $.078 * *$ & $.054 *$ & .022 & .015 \\
\hline Service as part of a class only & .007 & -.007 & .028 & .033 & .023 & -.002 & .034 \\
\hline $\begin{array}{l}\text { Service with a class and student } \\
\text { organization }\end{array}$ & .022 & .014 & .021 & $.077 * *$ & .037 & .024 & $.073 * *$ \\
\hline $\begin{array}{l}\text { Service with a class and on one's } \\
\text { own }\end{array}$ & .012 & -.019 & -.006 & .013 & .009 & .017 & $.057 *$ \\
\hline $\begin{array}{l}\text { Service with a student } \\
\text { organization and on one's own }\end{array}$ & .025 & $.067 *$ & $.081 * *$ & $.112 * * *$ & $.060 *$ & $.078 * *$ & $.097 * * *$ \\
\hline $\begin{array}{l}\text { Service with a class, a student } \\
\text { organization, and on one's own }\end{array}$ & .033 & .043 & $.058 *$ & $.077 * *$ & $.061 *$ & .036 & $.052 *$ \\
\hline $\begin{array}{l}\text { Service with a class, a student } \\
\text { organization, on one's own, and in } \\
\text { work study }\end{array}$ & -.012 & -.006 & -.013 & .019 & .018 & .007 & .030 \\
\hline $\begin{array}{l}\text { Service in work study-related } \\
\text { contexts }\end{array}$ & .031 & .036 & .027 & .042 & .022 & $.057 *$ & $.085 * *$ \\
\hline Female & .029 & .048 & .051 & .025 & .035 & .038 & .006 \\
\hline African American & .049 & .009 & -.015 & .025 & -.003 & .041 & .034 \\
\hline American Indian & .029 & .006 & -.020 & .020 & -.014 & .012 & .025 \\
\hline $\begin{array}{l}\text { Asian American or Pacific } \\
\text { Islander }\end{array}$ & $-.076 * *$ & $-.085 * *$ & $-.098 * *$ & -.030 & $-.052 *$ & -.046 & $-.066 * *$ \\
\hline Hispanic or Latino & .019 & -.001 & .011 & .021 & .001 & -.004 & $.047 *$ \\
\hline Full-time & -.006 & .005 & .002 & -.015 & -.006 & -.024 & -.029 \\
\hline Transfer & .001 & .030 & .024 & -.005 & .027 & .025 & .009 \\
\hline First Generation & -.042 & -.010 & .026 & .030 & -.006 & .008 & .017 \\
\hline Class Level & $.080 * *$ & $.071 *$ & .043 & .060 & $.056^{*}$ & $.088 * *$ & .048 \\
\hline Sociocultural Discussions & $.236 * * *$ & $.226 * * *$ & $.159 * * *$ & $.198 *$ & $.187 * * *$ & $.382 * * *$ & $.273 * * *$ \\
\hline
\end{tabular}




\begin{tabular}{|c|c|c|c|c|c|c|c|}
\hline College Leadership & $.330 * * *$ & $.108^{* *}$ & $.134 * * *$ & $.058 * * *$ & $.094 * *$ & $.073 *$ & $.114 * * *$ \\
\hline Pre-College Leadership Efficacy & $-.092 * *$ & -.040 & -.034 & .035 & .042 & -.013 & $.064 *$ \\
\hline $\begin{array}{l}\text { Pre-College Socially Responsible } \\
\text { Leadership }\end{array}$ & $.169 * *$ & $.302^{* * * *}$ & $.333 * * *$ & $.359 * * *$ & $.348 * * *$ & $.271 * * *$ & $.243 * * *$ \\
\hline $\begin{array}{l}\text { Pre-College Leadership } \\
\text { Antecedents }\end{array}$ & $.050 * * *$ & .019 & $.071^{*}$ & $.127 * * *$ & $.101 * *$ & .004 & $.143 * * *$ \\
\hline$R^{2}$ & $30.5 \%$ & $25.4 \%$ & $27.4 \%$ & $35.2 \%$ & $32.1 \%$ & $34.4 \%$ & $38.7 \%$ \\
\hline
\end{tabular}

\section{Discussion}

Several themes emerge from our results that are noteworthy and relevant toward understanding the intersections between community engagement and leadership development. It appears that college students who participate in community service opportunities on their own - without the formal structure of classes, student organizations, or work study - were more likely to work for positive change on behalf of the community (citizenship); work with others in a common effort (collaboration); have the passion, intensity, and duration to drive collective efforts (commitment); work with shared aims and purposes (common purpose); think, feel, and behave with consistency (congruence); have awareness of the beliefs, values, attitudes, and emotions that motivate one to take action (consciousness of self); and, hold respect for others and a willingness to hear others' views (controversy with civility). Students who are motivated to conduct service on their own - about one-third of the students in our study - likely exhibit these traits due to their personal passion toward promoting social change. After all, they sought out community service on their own.

While participation in service through student organizations and no other contexts was only significant in the models predicting collaboration and common purpose, students who participated in service on their own and with a student organization reported greater socially responsible leadership in all areas save for consciousness of self. Those results suggest that students who have the personal motivation to engage in service and also find student organizations in which to participate in service reap greater benefits than students who participate in service through student organizations alone.

Community service participation conducted in a class was only significantly associated with students' socially responsible leadership when in combination with either participation in student organizations or participation on one's own. The most effective combination in this regard was participation in service in classes, student organizations, and on one's own - students who engaged in service through these means reported higher values on four of the socially responsible leadership scales (commitment, collaboration, common purpose, and 
citizenship) than those who participated in the class context alone (which was not significant in any of the models). Students' participation in community service through a class only was not the only non-significant predictor in our models $p$ participation in a combination of all four contexts through work study, in a class, through a student organization, and on their own was also non-significant.

In examining each model, it is evident that community service in several contexts is most influential in predicting students' socially responsible leadership values of collaboration, common purpose, and citizenship. This finding also emerged when examining the size of the standardized coefficients, which were largest in the collaboration, common purpose, and citizenship models and were sometimes larger than the pre-college and college controls. These appear to be potential areas in which students who engage in community service tend to benefit with regards to their socially responsible leadership.

Several of the control variables consistently and positively predicted students' socially responsible leadership; for example, students' sociocultural discussions, college leadership, and pretests for socially responsible leadership emerged as significant in all of our models. These areas appear to be the most powerful indicators of socially responsible leadership and were often greater predictors of socially responsible leadership compared with the community service variables in our models.

\section{Recommendations}

It is significant that students who participated in community service on their own reported higher social change leadership. Due to survey limitations, we were unable to fully capture whether these students had connected with a university community engagement office to seek resources related to participation in community service, locate a community organization in which to serve, or undertake training regarding community service. If students are indeed seeking community service opportunities on their own, this presents a strong case for colleges and universities to continue to provide or expand community engagement offices that can help connect students with community organizations, offer advising services to help students refine their goals and expectations, and provide structured opportunities for reflection.

While it makes sense that students who have a genuine passion for social change will seek service opportunities on their own, this also presents a potentially missed opportunity to participate in community service that may provide students the opportunity to connect with other students, make intentional connections to their academic work, and engage in reflection. Previous research has suggested 
that students who participate in community service through their own have a lower sense of belonging on campus than students who participate through more formal structures such as student organizations (Soria, Troisi, \& Stebleton, 2012); therefore, it is recommended that practitioners seek ways to connect these students who engage in community service on their own to other students also interested in service.

While Sessa, Matos, and Hopkins (2009) suggested that service-learning is a viable alternative for teaching leadership, our research suggested that students who participated in service in classes did not report greater socially responsible leadership. It is likely the case that students participated in community service or service learning in a wide variety of classes in many disciplines; therefore, as a consequence, they likely did not engage in service that always offered reflection, collaboration, a shared purpose, or other opportunities to connect service with students' personal values. Hoover and Webster (2004) recommended that faculty conducting service learning activities provide students with greater opportunities to learn about other students and that allow students to move outside of their comfort zones. The authors also recommend that students participating in service learning should receive focused opportunities to reflect upon their role in service learning and that service should not be a "one time event" (Hoover \& Webster, 2004, p. 61). Ultimately, institutions should seek to provide courses and opportunities where community engagement plays a strong role and express the importance of leadership development within these contexts (Ricketts \& Bruce, 2008).

There are several ways in which service through organizations can be enhanced to include socially responsible leadership development; for example, students who participate in co-curricular activities can be offered complementary opportunities to participate in short-term leadership development programs, which can effectively provide students with lasting socially responsible leadership development and an integrated sense of thinking about leadership (Rosch \& Caza, 2012). According to Rosch and Caza (2012), short-term programs can also be fiscally efficient and provide the means to scale up to new initiatives. Ewing, Bruce, and Ricketts (2009) also suggested that practitioners can also place less emphasis upon leadership roles in co-curricular student organizations and more emphasis on providing opportunities for individuals to gain membership to organizations that match their personal or professional goals.

Many co-curricular leadership programs and leadership courses already integrate community service as the praxis for leadership theory. Other disciplinary courses implement service learning and leadership in an effort to provide hands-on experience in applying course content to a current community issue or problem (McCarthy \& Tucker, 2002). Within any disciplinary course, faculty can help 
students to make strong and lasting connections between community engagement and leadership development. Leadership programs can consider collaborations with traditionally distinct offices like those coordinating volunteering and servicelearning. Going even further, institutions could begin to look at community service as one vital aspect of leadership development work on campus. In addition, community service certificate programs and transcript notation are common strategies to encourage participation among undergraduates. Student organizations based on community service can provide opportunities for students to engage in a broad range of service activities.

Finally, we recommend future research be undertaken to examine connections between engagement in community service, service learning, and leadership development. Longitudinal research can provide insights into the ways in which short-term and long-term community service engagement continues to impact students' development of socially responsible leadership. Qualitative research can also reveal the means through which some community service contexts yielded greater socially responsible leadership; specifically, we believe it would be interesting to interview those students who participate in community service on their own to learn how this seemingly unstructured form of service contributes to student outcomes. Future inquiries into the ways in which community and civic engagement enhance students' leadership development can be leveraged to develop best practices for teaching leadership experientially on college campuses. 


\section{References}

Astin, A. W. (1993). What matters in college? Four critical years revisited. San Francisco: Jossey-Bass.

Astin, A. W., \& Astin, H. S. (2000). Leadership reconsidered: Engaging higher education in social change. Battle Creek, MI: W. K. Kellogg Foundation.

Astin, A. W., \& Sax, L. J. (1998). How undergraduates are affected by service participation. Journal of College Student Development, 39(3), 251-263.

Astin, H. S. (1996, July-August). Leadership for social change. About Campus, 4-10.

Campus Compact (2011). 2010 annual membership survey results: Executive summary. Boston: Campus Compact.

Cress, C. M., Astin, H. S., Zimmerman-Oster, K., \& Burkhardt, J. C. (2001). Developmental outcomes of college students' involvement in leadership activities. Journal of College Student Development, 42, 15-27.

Dugan, J. P. (2006). Involvement and leadership: A descriptive analysis of socially responsible leadership. Journal of College Student Development, 47(3), 335-343.

Dugan, J. P. (2008). Exploring relationships between fraternity and sorority membership and socially responsible leadership. Oracle: The Research Journal of the Association of Fraternity Advisors, 3(2), 16-25.

Dugan, J. P., Kodama, C. M., \& Gebhardt, M. C. (2012). Race and leadership development among college students: The additive value of collective racial esteem. Journal of Diversity in Higher Education, 5(3), 174-189.

Dugan, J. P., \& Komives, S. R. (2010). Influences on college students' capacities for socially responsible leadership. Journal of College Student Development, 51(5), 525-549.

Dugan, J. P., Komives, S. R., \& Segar, T. C. (2009). College student capacity for socially responsible leadership: Understanding norms and influences of race, gender, and sexual orientation. NASPA Journal, 45(4), 475-500.

Ewing, J. C., Bruce, J. A., \& Ricketts, K. G. (2009). Effective leadership 
development for undergraduates: How important is active participation in collegiate organziations. Journal of Leadership Education, 7(3), 118-132.

Eyler, J., Giles, D., \& Grey, C. (1999). At a glance: What we know about the effects of service-learning on students, faculty, institutions, and communities, 1993-1999. Minneapolis, MN: National Service-Learning Clearinghouse, University of Minnesota.

Giles, D., \& Eyler, J. (1994). The impact of a college community service laboratory on students' personal, social, and cognitive outcomes. Journal of Adolescence, 17(4), 327-339.

Hoover, T. S., \& Webster, N. (2004). Modeling service learning for future leaders of youth organizations. Journal of Leadership Education, 3(3), 58-62.

Liu, A., Ruiz, S., DeAngelo, L., \& Pryor, J. (2009). Findings from the 2008 administration of the College Senior Survey (CSS): National aggregates. Los Angeles: Higher Education Research Institute, UCLA.

Markus, G., Howard, J., \& King, D. (1993). Integrating community service and Classroom instruction enhances learning: Results from an experiment. Education Evaluation \& Policy Analysis, 15(4), 410-419.

McCarthy, A. M., \& Tucker, M. L. (2002). Encouraging community service Through service learning. Journal of Management Education, 26(6), 629-647.

National Survey of Student Engagement (2010). Major differences: Examining Student engagement by field of study. Retrieved from http://nsse.iub.edu/html/annual_results.cfm.

Nishishiba, M., \& Kecskes, K. (2012). Capacity building for the common good: PSU's interdisciplinary minor in civic leadership. Journal of College and Character, 13(1), 1-13.

Oesterle, S., Johnson, M., \& Mortimer, J. (2004). Volunteerism during the transition to adulthood: A life course perspective. Social Forces, 82, 1123-1149.

Perry, J., \& Katula, M. (2001). Does service affect citizenship? Administration and Society, 33, 330-365.

Ricketts, K . G., \& Bruce, J. A. (2008). How today's undergraduate students see 
themselves as tomorrow's socially responsible leaders. Journal of Leadership Education, 7(1), 24-42.

Rosch, D. M., \& Caza, A. (2012). The durable effects of short-term programs on student leadership development. Journal of Leadership Education, 11(1), $28-48$.

Seider, S., \& Butin, D. W. (2012). Introduction to special issue on the "The Future of Community Engagement in Higher Education." Journal of College and Character, 13(1), 1-6.

Sessa, V. I., Matos, C., \& Hopkins, C. A. (2009). Evaluating a college leadership course: What do students learn in a leadership course with a servicelearning component and how deeply do they learn it? Journal of Leadership Education, 7(3), 167-200.

Soria, K. M., Troisi, J. N., \& Stebleton, M. J. (2012). Reaching out, connecting within: Community service participation and sense of belonging among college students. Higher Education in Review, 9, 65-85.

The National Task Force on Civic Learning and Democratic Engagement (2012). A crucible moment: College learning and democracy's future.

Washington, DC: Association of American Colleges and Universities.

Tyree, T. M. (1998). Designing an instrument to measure the socially responsible Leadership using the social change model of leadership development. Dissertation Abstracts Ｉnternational, 59 (06), 1945. (AAT 9836493)

Vogelgesang, L. J., \& Astin, A. W. (2000). Comparing the effects of servicelearning and community service. Michigan Journal of Community Service Learning, 7, 25-34.

Yates, M., \& Youniss, J. (1996). A developmental perspective on community service in adolescence. Social Development, 5(1), 85-111.

Youniss, J., \& Yates, M. (1997). Community service and social responsibility in youth. Chicago: University of Chicago Press.

Zimmerman-Oster, K., \& Burkhardt, J. C. (1999). Leadership in the making: Impact and insights from leadership development programs in U. S. colleges and universities. Battle Creek, MI: W. K. Kellogg Foundation. 


\section{Author Biographies}

Krista Soria is a doctoral candidate in educational policy and administration (higher education emphasis) at the University of Minnesota-Twin Cities. Krista is also an adjunct faculty with the University's leadership minor program and an analyst with the Office of Institutional Research. Her research interests include leadership development, community engagement, and social class in higher education.

June Nobbe, Ph.D., serves as Director of the Office for Leadership Education \& Development - Undergraduate Programs at the University of Minnesota-Twin Cities and provides oversight for curricular and co-curricular leadership programs. June has provided administrative leadership for the Leadership Minor since 2001 and has worked at the University of Minnesota-Twin Cities for 28 years in several capacities in the Division of Student Affairs. In addition to her administrative roles, June was awarded a research grant from the NASPA Foundation and recently completed her doctorate in educational policy and administration. Her research focus is the civic mission of public higher education.

Alexander Fink is a doctoral student in social work at the University of Minnesota-Twin Cities. Alex coordinates new instructor development and teaches several undergraduate leadership classes at the University of Minnesota. He brings youth work and leadership development orientations to social work leadership development, where he is interested in leadership development in social services, youth cultural and political geographies and meaning making, mentoring relationships, and skill, craft, practice development models for social services practitioners. 